\title{
THE EFFECT OF CHANGES IN VENTILATION AND PULMONARY BLOOD FLOW ON THE DIFFUSING CAPACITY OF THE LUNG* $\dagger$
}

\author{
By G. M. TURINO, $¥$ M. BRANDFONBRENER\& AND A. P. FISHMAN
}

\begin{abstract}
(From the Department of Medicine, Columbia University, College of Physicians and Surgeons, and the Cardiorespiratory Laboratory of the Presbyterian Hospital, New York, N. Y.)
\end{abstract}

(Submitted for publication December 29, 1958; accepted February 19, 1959)

The "pulmonary diffusing capacity" for carbon monoxide $\left(\mathrm{DL}_{\mathrm{CO}}\right)$ is of interest as a measure of the extent and permeability of the alveolarcapillary interface. However, its use for this purpose is subject to three major types of error: 1) undetected influences of other physiologic factors, such as changes in pulmonary blood flow, the volume of air in the lungs and the distribution of inspired air ; 2) disregarded characteristics of the test substance, such as altered rates of chemical combination of carbon monoxide with hemoglobin at different oxygen tensions; and 3) artifacts due to the test procedure itself, such as those introduced by deliberate respiratory maneuvers.

These factors assume different proportions in different methods of measurement.

For the single breath technique, some of these factors, such as the volume of air in the lungs (1-3) and the rate of combination of hemoglobin with carbon monoxide, have been extensively studied $(4,5)$. For the steady state methods, many remain to be assessed.

Before applying a steady state method to a variety of physiological problems, it seemed pertinent to us to delineate some factors which could affect the DLco.

The present study considers specifically the effect of minute ventilation and pulmonary blood flow on the diffusing capacity for carbon monoxide determined by a steady state method.

\footnotetext{
* This investigation was supported in part by a research grant [Public Health Service Grant H-2299 (C)] from the National Heart Institute of the National Institutes of Health, with additional support from the American Heart Association and the New York Heart Association.

$\dagger$ Presented in part at the 76th Meeting of the American Physiological Society, Atlantic City, N. J., April, 1956.

$\ddagger$ Senior Research Fellow, New York Heart Association.

$\$$ Work done during tenure of an American Heart Postdoctoral Fellowship. Present address: Veterans Administration Research Hospital, Chicago, Ill.
}

\section{GENERAL PRINCIPLES}

The diffusing capacity of the lung for carbon monoxide, the pulmonary blood flow and the minute ventilation all increase during exercise. In order to determine if the change in minute ventilation or the change in pulmonary blood flow or both, influence $\mathrm{DL}_{\mathrm{CO}}$, three different approaches were used: 1) Minute ventilation was increased more than pulmonary blood flow by exercising subjects with only a limited capacity to augment cardiac output; 2) minute ventilation was again increased in excess of a change in pulmonary blood flow by having subjects undergo voluntary hyperpnea; and 3) blood flow through each lung was varied simultaneously in such a way that blood flow increased in one and decreased in the other while minute ventilation remained virtually unchanged.

\section{SUBJECTS AND METHODS}

Rest and exercise. Thirteen subjects with mitral stenosis on the basis of rheumatic heart disease were studied both at rest and during exercise. For the sake of comparison, DLco was also measured in 21 normal subjects at rest (Table I) and an additional 15 normal subjects were studied both at rest and during exercise (Table II).

These studies involved the simultaneous measurement of minute ventilation, cardiac output and DLco. Cardiac output was measured by the Fick principle, using oxygen as the test gas and entailed: 1) open circuits for the administration of inspired gas as well as for the collection and sampling of expired gas; 2 ) cardiac catheterization for sampling of pulmonary arterial blood; and 3) cannulation of a brachial artery for the sampling of mixed arterial blood. For the estimation of $\mathrm{DL}_{\mathrm{co}}, 0.1$ per cent carbon monoxide in air was substituted for ambient air for four to six minutes of the test periods at rest and during exercise.

Exercise was performed in the supine position using a special pedal-pulley device attached to the fluoroscopic table. In all subjects but four, a single level of exercise was used; in these four, exercise was continued for a second period at a greater intensity. Midway through the gas collection period, samples of systemic and pulmonary 
arterial blood were drawn for the measurements of oxygen contents, as well as carbon dioxide and carbon monoxide tensions.

The steady state method for measuring DLco proposed by Filley, MacIntosh and Wright (6) was modified in two respects: 1) The carbon monoxide tension of expired gas was measured by an infrared physical analyzer ${ }^{1}$ and 2) the carbon monoxide content of arterial blood was measured by the method of Allen and Root (7); this value was used to calculate the tension of carbon monoxide in arterial blood by means of the Haldane relationship (8). For this calculation, it was assumed that in normal subjects, the mean difference in oxygen tension between alveolar gas and arterial blood is approximately $10 \mathrm{~mm}$. $\mathrm{Hg}$. Since the removal of $\mathrm{CO}$ from physical solution may continue after blood has left the pulmonary capillary, it is clear that arterial pCO can only underestimate the mean back pressure of carbon monoxide in the pulmonary capillary (4). In this study, therefore, arterial pCO is used as a minimal estimate of mean capillary pressure for carbon monoxide.

The $\mathrm{pCO}_{2}$ of arterial blood was determined from the line charts of Van Slyke and Sendroy (9). For this measurement, the blood $\mathrm{CO}_{2}$ content and oxyhemoglobin saturation were determined by the method of Van Slyke and Neill (10) and pH by the MacInnes-Belcher glass elec-

${ }^{1}$ Liston-Becker Division of Beckman Instrument Co., Stamford, Conn. trode. The oxygen and carbon dioxide contents of expired gas were measured in a micro-Scholander apparatus (11).

To relate pulmonary arterial pressures to $\mathrm{DL}_{\mathrm{co}}$, blood pressures were recorded by means of Statham transducers coupled with a multichannel oscilloscope recording apparatus. ${ }^{2}$

Voluntary hyperpnea. In 10 of the normal subjects and four of the patients with rheumatic heart disease, the observations at rest and during exercise were supplemented by similar measurements during a period of voluntary hyperpnea. The level of ventilation during hyperpnea was set to correspond to that which was reached spontaneously during exercise. In order to avoid depletion of carbon dioxide and to preserve a steady state, 3 or 5 per cent $\mathrm{CO}_{2}$ was added to the inspired mixture in accord with the level of minute ventilation. The actual sequence was as follows: After measurements at rest and during exercise, the subjects underwent a final period of hyperpnea which consisted of breathing 3 to 5 per cent $\mathrm{CO}_{2}$ in air for 14 minutes followed by an additional four minutes of the same inspired mixture, plus 0.1 per cent CO. During the last two minutes, blood and expired gas samples were collected in the usual way for the measurement of pulmonary blood flow and DLco.

Unilateral occlusion of one pulmonary artery. In six subjects with either a normal cardiorespiratory system or

2 Electronics for Medicine, White Plains, N. Y.

TABLE I

The pulmonary diffusing capacity in 21 normal subjects at rest*

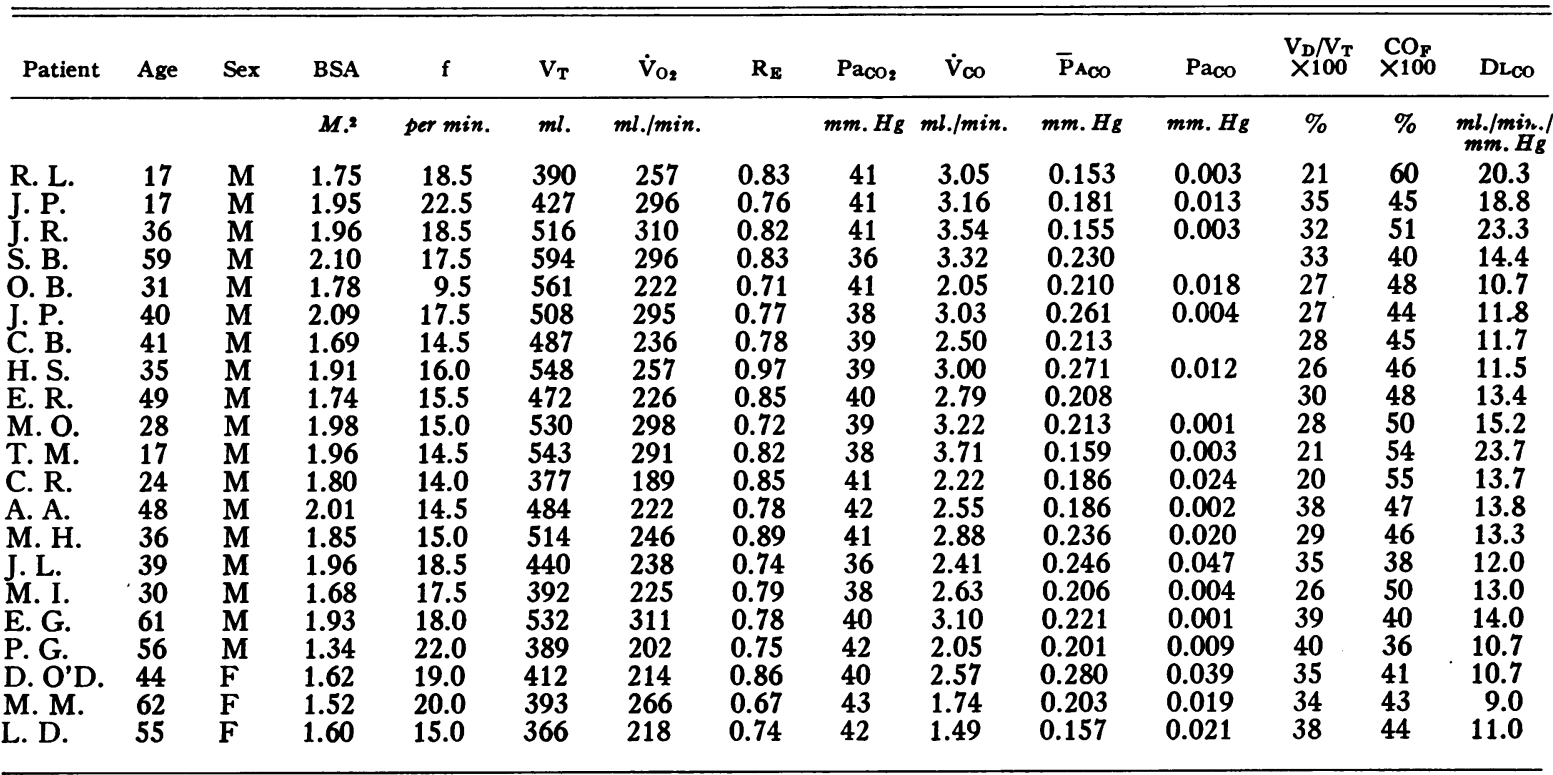

* Symbols : $\mathrm{BSA}=$ body surface area, square meters; $\mathrm{f}=$ respiratory frequency, breaths per minute; $\mathrm{V}_{\mathbf{T}}=$ tidal volume, $m$ l. BTPS; $\dot{\mathrm{V}}_{\mathrm{O}_{2}}=$ oxygen consumption, ml. per minute STPD; $\mathrm{R}_{\mathrm{E}}=$ respiratory exchange ratio, expired air; $\mathrm{PaCO}_{2}=$ tension of carbon dioxide in arterial blood, $\mathrm{mm}$. $\mathrm{Hg} ; \mathrm{V}_{\mathrm{co}}=$ uptake of carbon monoxide, ml. per minute STPD; $\overline{\mathrm{P}}_{\mathrm{ACO}}=$ mean alveolar carbon monoxide tension, $\mathrm{mm} . \mathrm{Hg} ; \mathrm{PaCO}=$ tension of carbon monoxide in arterial blood, $\mathrm{mm}$. $\mathrm{Hg} ; \mathrm{V}_{\mathrm{D}} / \mathrm{V}_{\mathrm{T}} \times 100=$ ratio of personal dead space (total dead space minus the instrument dead space) to tidal volume, per cent; $\mathrm{COF} \times 100$ = ratio of the uptake of carbon monoxide to the volume of carbon monoxide inspired, per cent; and $\mathrm{DL}_{\mathrm{co}}=$ diffusing capacity of the lung for carbon monoxide, $\mathrm{ml}$. per minute per $\mathrm{mm}$. $\mathrm{Hg}$. 
TABLE II

The respiration, circulation and pulmonary diffusing capacity in normal subjects at rest, during exercise and voluntary hyperpnea*

\begin{tabular}{|c|c|c|c|c|c|c|c|c|c|c|c|c|c|c|}
\hline $\begin{array}{l}\text { Patient, } \\
\text { Age, Sex, } \\
\text { BSA/M.2 }\end{array}$ & State & f & $\mathbf{V}_{\mathbf{T}}$ & $\dot{\mathbf{V}}_{\mathbf{E}}$ & $\mathrm{V}_{02}$ & $\mathbf{R}_{\mathbf{F}}$ & $\mathrm{PaCO}_{2}$ & $V_{\infty}$ & $\overline{\mathrm{P}}_{\mathrm{ACO}}$ & $\mathrm{Paco}$ & $\begin{array}{l}\mathrm{VD}_{\mathrm{D}} / \mathrm{V}_{\mathrm{T}} \\
\times 100\end{array}$ & $\begin{array}{l}\mathrm{CO}_{\mathrm{F}} \\
\times 100\end{array}$ & $\mathrm{DL}_{\mathrm{co}}$ & $\dot{\mathbf{Q}}$ \\
\hline & & per min. & $m l$. & L./min. & ml./min. & & $m m . \mathrm{Hg}$ & ml./min. & $m m . \mathrm{Hg}$ & $m m . \mathrm{Hg}$ & $\%$ & $\%$ & & L./min. \\
\hline \multicolumn{15}{|c|}{ Rest and exercise } \\
\hline $\begin{array}{l}\text { H. K. } \\
24, F \\
1.68\end{array}$ & $\begin{array}{l}\text { Rest } \\
\text { Exer. } \\
\text { Exer. }\end{array}$ & $\begin{array}{l}18.5 \\
23 \\
26\end{array}$ & $\begin{array}{l}542 \\
839 \\
945\end{array}$ & $\begin{array}{r}8.35 \\
16.05 \\
20.42\end{array}$ & $\begin{array}{l}260 \\
498 \\
636\end{array}$ & $\begin{array}{l}0.76 \\
0.89 \\
0.99\end{array}$ & $\begin{array}{l}40 \\
39 \\
43\end{array}$ & $\begin{array}{l}2.18 \\
4.78 \\
5.31\end{array}$ & & & $\begin{array}{l}26 \\
29 \\
20\end{array}$ & $\begin{array}{l}35 \\
36 \\
29\end{array}$ & $\begin{array}{r}8.9 \\
19.8 \\
19.1\end{array}$ & $\begin{array}{l}6.7 \\
8.30 \\
8.96\end{array}$ \\
\hline $\begin{array}{l}\text { A. S. } \\
28, \dot{M} \\
1.65\end{array}$ & $\begin{array}{l}\text { Rest } \\
\text { Exer. } \\
\text { Exer. }\end{array}$ & $\begin{array}{l}17 \\
34 \\
40\end{array}$ & $\begin{array}{l}439 \\
642 \\
768\end{array}$ & $\begin{array}{r}6.16 \\
18.01 \\
25.30\end{array}$ & $\begin{array}{l}284 \\
595 \\
706\end{array}$ & $\begin{array}{l}0.66 \\
0.88 \\
0.95\end{array}$ & $\begin{array}{l}32 \\
33 \\
32\end{array}$ & $\begin{array}{l}2.94 \\
6.22 \\
6.66\end{array}$ & & & $\begin{array}{l}19 \\
27 \\
33\end{array}$ & $\begin{array}{l}51 \\
36 \\
27\end{array}$ & $\begin{array}{l}14.1 \\
22.2 \\
22.2\end{array}$ & $\begin{array}{r}8.6 \\
12.4 \\
13.8\end{array}$ \\
\hline $\begin{array}{l}\text { N. L. } \\
26, \mathrm{~F} \\
1.51\end{array}$ & $\begin{array}{l}\text { Rest } \\
\text { Exer. } \\
\text { Exer. } \\
\text { Rest }\end{array}$ & $\begin{array}{l}19 \\
29 \\
30 \\
17\end{array}$ & $\begin{array}{l}362 \\
597 \\
834 \\
416\end{array}$ & $\begin{array}{r}5.66 \\
14.20 \\
20.60 \\
5.83\end{array}$ & $\begin{array}{l}216 \\
618 \\
802 \\
254\end{array}$ & $\begin{array}{l}0.91 \\
0.89 \\
0.96 \\
0.88\end{array}$ & $\begin{array}{l}40 \\
38.5 \\
35 \\
40\end{array}$ & $\begin{array}{l}2.46 \\
4.89 \\
6.10 \\
2.49\end{array}$ & $\begin{array}{l}0.192 \\
0.344 \\
0.393 \\
0.185\end{array}$ & $\begin{array}{l}0.015 \\
0.028 \\
0.061 \\
0.030\end{array}$ & $\begin{array}{l}22 \\
20 \\
22 \\
23\end{array}$ & $\begin{array}{l}51 \\
37 \\
31 \\
49\end{array}$ & $\begin{array}{l}14.0 \\
15.5 \\
18.4 \\
16.0\end{array}$ & $\begin{array}{r}5.02 \\
9.50 \\
11.30 \\
6.20\end{array}$ \\
\hline $\begin{array}{l}\text { C. M. } \\
34, \mathrm{~F} \\
1.58\end{array}$ & $\begin{array}{l}\text { Rest } \\
\text { Exer. }\end{array}$ & $\begin{array}{l}19 \\
36\end{array}$ & $\begin{array}{l}349 \\
585\end{array}$ & $\begin{array}{r}5.39 \\
17.15\end{array}$ & $\begin{array}{l}202 \\
554\end{array}$ & $\begin{array}{l}0.78 \\
0.84\end{array}$ & & & & & $\begin{array}{l}27 \\
37\end{array}$ & $\begin{array}{l}44 \\
28\end{array}$ & $\begin{array}{l}10.0 \\
15.4\end{array}$ & \\
\hline $\begin{array}{l}\text { D. E. } \\
36, \dot{M} \\
2.20\end{array}$ & $\begin{array}{l}\text { Rest } \\
\text { Exer. } \\
\text { Exer. }\end{array}$ & $\begin{array}{l}13 \\
19.5 \\
21\end{array}$ & $\begin{array}{r}827 \\
1,055 \\
1,310\end{array}$ & $\begin{array}{r}8.79 \\
16.82 \\
22.50\end{array}$ & $\begin{array}{r}320 \\
954 \\
1,051\end{array}$ & $\begin{array}{l}0.82 \\
0.87 \\
0.92\end{array}$ & $\begin{array}{l}31 \\
33 \\
39\end{array}$ & & & & $\begin{array}{l}25 \\
28 \\
23\end{array}$ & $\begin{array}{l}47 \\
41 \\
38\end{array}$ & $\begin{array}{l}16.7 \\
24.8 \\
26.3\end{array}$ & \\
\hline \multicolumn{15}{|c|}{ Rest, exercise and voluntary hyperpnea $\dagger$} \\
\hline $\begin{array}{l}\text { A. S. } \\
24, \dot{M} \\
1.89\end{array}$ & $\begin{array}{l}\text { Rest } \\
\text { Exer. } \\
\text { Hyper. }\end{array}$ & $\begin{array}{l}12 \\
21 \\
20\end{array}$ & $\begin{array}{r}519 \\
1,007 \\
1,270\end{array}$ & $\begin{array}{r}5.07 \\
17.25 \\
20.70\end{array}$ & $\begin{array}{l}256 \\
694 \\
255\end{array}$ & $\begin{array}{l}0.74 \\
1.06 \\
1.00\end{array}$ & $\begin{array}{l}39.5 \\
38.5 \\
36.5\end{array}$ & $\begin{array}{l}2.56 \\
7.54 \\
7.24\end{array}$ & & & $\begin{array}{l}22 \\
17 \\
39\end{array}$ & $\begin{array}{l}54 \\
45 \\
36\end{array}$ & & $\begin{array}{l}6.24 \\
8.47 \\
5.67\end{array}$ \\
\hline $\begin{array}{l}\text { M. M. } \\
27, \mathrm{~F} \\
1.61\end{array}$ & $\begin{array}{l}\text { Rest } \\
\text { Exer. } \\
\text { Hyper. }\end{array}$ & $\begin{array}{l}15.5 \\
22.0 \\
20.5\end{array}$ & $\begin{array}{r}506 \\
1,012 \\
825\end{array}$ & $\begin{array}{r}6.45 \\
18.34 \\
15.60\end{array}$ & $\begin{array}{l}230 \\
542 \\
283\end{array}$ & $\begin{array}{l}0.80 \\
1.07 \\
0.78\end{array}$ & $\begin{array}{l}33 \\
36 \\
37\end{array}$ & & & & $\begin{array}{l}22 \\
31 \\
31\end{array}$ & & & $\begin{array}{r}6.76 \\
10.04 \\
8.09\end{array}$ \\
\hline $\begin{array}{l}\text { C. C. } \\
44, \dot{M} \\
1.81\end{array}$ & $\begin{array}{l}\text { Rest } \\
\text { Exer. } \\
\text { Hyper. } \\
\text { Hyper. }\end{array}$ & $\begin{array}{l}8 \\
20 \\
10.5 \\
26.0\end{array}$ & $\begin{array}{r}1,045 \\
925 \\
1,776 \\
1,120\end{array}$ & $\begin{array}{r}6.86 \\
15.19 \\
15.31 \\
23.70\end{array}$ & $\begin{array}{l}254 \\
664 \\
282 \\
280\end{array}$ & $\begin{array}{l}0.89 \\
0.90 \\
0.82 \\
0.92\end{array}$ & $\begin{array}{l}35 \\
37 \\
40 \\
38\end{array}$ & $\begin{array}{l}3.70 \\
5.84 \\
5.42 \\
6.21\end{array}$ & & & $\begin{array}{l}29 \\
30 \\
35 \\
46\end{array}$ & $\begin{array}{l}55 \\
38 \\
35 \\
26\end{array}$ & & $\begin{array}{l}4.38 \\
7.64 \\
5.42 \\
4.59\end{array}$ \\
\hline $\begin{array}{l}\text { L. S. } \\
20, \dot{F} \\
1.61\end{array}$ & $\begin{array}{l}\text { Rest } \\
\text { Exer. } \\
\text { Hyper. }\end{array}$ & $\begin{array}{l}10.5 \\
29.5 \\
22\end{array}$ & $\begin{array}{l}539 \\
905 \\
899\end{array}$ & $\begin{array}{r}4.63 \\
27.80 \\
16.20\end{array}$ & $\begin{array}{l}203 \\
704 \\
332\end{array}$ & $\begin{array}{l}0.79 \\
1.04 \\
0.51\end{array}$ & $\begin{array}{l}34.5 \\
35 \\
40\end{array}$ & $\begin{array}{l}2.35 \\
7.90 \\
5.92\end{array}$ & & & $\begin{array}{l}19 \\
26 \\
23\end{array}$ & $\begin{array}{l}60 \\
41 \\
42\end{array}$ & & $\begin{array}{l}5.34 \\
9.38 \\
6.74\end{array}$ \\
\hline $\begin{array}{l}\text { R. G. } \\
15, \mathrm{M} \\
1.62\end{array}$ & $\begin{array}{l}\text { Rest } \\
\text { Exer. } \\
\text { Hyper. }\end{array}$ & $\begin{array}{l}19.5 \\
30 \\
15\end{array}$ & $\begin{array}{r}482 \\
611 \\
1,125\end{array}$ & $\begin{array}{r}7.80 \\
15.20 \\
14.00\end{array}$ & $\begin{array}{l}183 \\
591 \\
263\end{array}$ & $\begin{array}{l}0.80 \\
0.90 \\
1.38\end{array}$ & $\begin{array}{l}36 \\
38 \\
26\end{array}$ & $\begin{array}{l}3.72 \\
5.84 \\
5.92\end{array}$ & & & $\begin{array}{l}26 \\
23 \\
23\end{array}$ & $\begin{array}{l}49 \\
39 \\
43\end{array}$ & & \\
\hline $\begin{array}{l}\mathrm{J} . \mathrm{R} . \\
26, \mathrm{M} \\
2.08\end{array}$ & $\begin{array}{l}\text { Rest } \\
\text { Exer. } \\
\text { Hyper. } \\
\text { Hyper. }\end{array}$ & $\begin{array}{c}12 \\
24 \\
4.3 \\
14\end{array}$ & $\begin{array}{r}678 \\
1,391 \\
3,020 \\
3,329\end{array}$ & $\begin{array}{r}6.55 \\
26.90 \\
10.52 \\
37.50\end{array}$ & $\begin{array}{r}353 \\
1,143 \\
452 \\
529\end{array}$ & $\begin{array}{l}0.71 \\
0.97 \\
0.98 \\
1.77\end{array}$ & $\begin{array}{l}40 \\
38 \\
36 \\
26\end{array}$ & & & & $\begin{array}{l}25 \\
20 \\
17 \\
31\end{array}$ & $\begin{array}{l}45 \\
35 \\
56 \\
26\end{array}$ & $\begin{array}{l}20.2 \\
27.1 \\
33.7 \\
27.1\end{array}$ & \\
\hline $\begin{array}{l}\mathrm{J}_{43, \mathrm{~J}} \mathrm{~J}_{\mathrm{M}} \\
1.59\end{array}$ & $\begin{array}{l}\text { Rest } \\
\text { Exer. } \\
\text { Rest } \\
\text { Hyper. }\end{array}$ & $\begin{array}{l}19 \\
25 \\
16 \\
25\end{array}$ & $\begin{array}{r}356 \\
1,077 \\
436 \\
1,544\end{array}$ & $\begin{array}{r}5.63 \\
22.40 \\
5.81 \\
31.85\end{array}$ & $\begin{array}{l}251 \\
934 \\
245 \\
350\end{array}$ & $\begin{array}{l}0.71 \\
1.10 \\
0.75 \\
0.43\end{array}$ & $\begin{array}{l}40 \\
40 \\
40 \\
46\end{array}$ & $\begin{array}{l}2.22 \\
7.05 \\
2.62 \\
7.89\end{array}$ & & & $\begin{array}{l}32 \\
36 \\
32 \\
32\end{array}$ & $\begin{array}{l}48 \\
36 \\
55 \\
28\end{array}$ & $\begin{array}{l}14.2 \\
23.0 \\
16.6 \\
28.9\end{array}$ & $\begin{array}{c}6.4 \\
10.74 \\
6.8 \\
8.14\end{array}$ \\
\hline $\begin{array}{l}\text { E. M. } \\
51, M \\
1.65\end{array}$ & $\begin{array}{l}\text { Rest } \\
\text { Exer. } \\
\text { Rest } \\
\text { Hyper. }\end{array}$ & $\begin{array}{l}17 \\
21.5 \\
17.5 \\
22\end{array}$ & $\begin{array}{r}366 \\
1,105 \\
380 \\
1,329\end{array}$ & $\begin{array}{r}5.17 \\
19.80 \\
5.53 \\
24.20\end{array}$ & $\begin{array}{l}218 \\
798 \\
240 \\
322\end{array}$ & $\begin{array}{l}0.75 \\
1.12 \\
0.65 \\
0.42\end{array}$ & $\begin{array}{l}40 \\
40 \\
40 \\
44\end{array}$ & $\begin{array}{l}2.04 \\
5.32 \\
2.12 \\
7.67\end{array}$ & $\begin{array}{l}0.149 \\
0.264 \\
0.176 \\
0.351\end{array}$ & $\begin{array}{l}0.012 \\
0.046 \\
0.056 \\
0.061\end{array}$ & $\begin{array}{l}35 \\
42 \\
36 \\
22\end{array}$ & $\begin{array}{l}47 \\
28 \\
45 \\
35\end{array}$ & $\begin{array}{l}14.9 \\
24.4 \\
17.6 \\
26.6\end{array}$ & $\begin{array}{r}6.61 \\
12.68 \\
7.50 \\
7.33\end{array}$ \\
\hline
\end{tabular}

* Symbols are the same as in Table I, plus: $\dot{\mathrm{V}}_{\mathrm{E}}=$ total ventilation (expired air), L. per minute, STPD and $\dot{\mathrm{Q}}=$ pulmonary blood flow, L. per minute.

t During voluntary hyperpnea, Subjects A. S., M. M. and C. C. breathed 3 per cent $\mathrm{CO}_{2}$ in air; Subjects J. J., E. M., B. K., J. I. and L. S. breathed 5 per cent $\mathrm{CO}_{2}$ in air; and Subjects R. G. and J. R. breathed ambient air. 
TABLE II-Continued

\begin{tabular}{|c|c|c|c|c|c|c|c|c|c|c|c|c|c|c|}
\hline $\begin{array}{l}\text { Patient, } \\
\text { Age. Sex, } \\
\text { BSA/M.2 }\end{array}$ & State & f & $\mathrm{V}_{\mathrm{T}}$ & $\dot{\mathrm{V}}_{\mathbf{E}}$ & $\dot{\mathrm{V}}_{\mathrm{O}_{2}}$ & $\mathbf{R}_{\mathbf{E}}$ & $\mathrm{PaCO}_{2}$ & $\dot{\mathrm{V}}_{\mathrm{co}}$ & $\overline{\mathrm{P}}_{\mathbf{A}_{\mathrm{CO} O}}$ & $\mathrm{~Pa}_{\mathrm{co}}$ & $\begin{array}{l}V_{\mathbf{D}} / V_{\mathbf{T}} \\
\times 100\end{array}$ & $\begin{array}{l}\mathrm{CO}_{F} \\
\times 100\end{array}$ & DLoO & $\dot{\mathbf{Q}}$ \\
\hline & & per min. & $m l$ & L./min. & ml. $/ m i n$ & & $m m . \mathrm{Hg}$ & ml./min. & $\mathrm{mm} \cdot \mathrm{Hg}$ & $\mathrm{mm} . \mathrm{Hg}$ & $\%$ & $\%$ & $\underset{\text { mm. }}{\operatorname{ml} . / \min . /}$ & L./min. \\
\hline $\begin{array}{l}\text { B. K. } \\
41, \mathrm{M} \\
1.79\end{array}$ & $\begin{array}{l}\text { Rest } \\
\text { Exer. } \\
\text { Rest } \\
\text { Hyper. }\end{array}$ & $\begin{array}{l}14 \\
28 \\
14 \\
24\end{array}$ & $\begin{array}{r}554 \\
937 \\
560 \\
1,234\end{array}$ & $\begin{array}{r}6.37 \\
21.58 \\
6.44 \\
24.00\end{array}$ & $\begin{array}{r}272 \\
1,104 \\
292 \\
291\end{array}$ & $\begin{array}{l}0.82 \\
1.06 \\
0.78 \\
0.80\end{array}$ & $\begin{array}{l}44 \\
47 \\
46 \\
51\end{array}$ & $\begin{array}{l}2.41 \\
7.28 \\
2.51 \\
8.57\end{array}$ & $\begin{array}{l}0.190 \\
0.306 \\
0.180 \\
0.280\end{array}$ & $\begin{array}{l}0.017 \\
0.026 \\
0.036 \\
0.063\end{array}$ & $\begin{array}{l}32 \\
25 \\
32 \\
27\end{array}$ & $\begin{array}{l}45 \\
38 \\
46 \\
40\end{array}$ & $\begin{array}{l}13.9 \\
26.1 \\
17.4 \\
39.6\end{array}$ & $\begin{array}{r}6.80 \\
16.20 \\
6.80 \\
7.67\end{array}$ \\
\hline $\begin{array}{l}\mathrm{J} . \mathrm{I} . \\
26, \mathrm{M} \\
1.77\end{array}$ & $\begin{array}{l}\text { Rest } \\
\text { Exer. } \\
\text { Hyper. }\end{array}$ & $\begin{array}{l}21 \\
31 \\
32\end{array}$ & $\begin{array}{l}370 \\
683 \\
720\end{array}$ & $\begin{array}{r}6.38 \\
17.35 \\
18.90\end{array}$ & $\begin{array}{l}259 \\
692 \\
370\end{array}$ & $\begin{array}{l}0.72 \\
0.92 \\
0.67\end{array}$ & $\begin{array}{l}43 \\
44 \\
42\end{array}$ & $\begin{array}{l}2.42 \\
5.16 \\
5.20\end{array}$ & $\begin{array}{l}0.270 \\
0.331 \\
0.293\end{array}$ & $\begin{array}{l}0.015 \\
0.029 \\
0.056\end{array}$ & $\begin{array}{l}27 \\
35 \\
46\end{array}$ & $\begin{array}{l}43 \\
32 \\
29\end{array}$ & $\begin{array}{r}9.5 \\
17.1 \\
21.9\end{array}$ & $\begin{array}{c}6.8 \\
10.2 \\
7.88\end{array}$ \\
\hline
\end{tabular}

a unilateral pulmonary lesion (Table III), DLco and pulmonary blood flow were measured for each lung separately during normal flow and during partial obstruction to flow through one pulmonary artery.

The measurement of blood flow through each lung separately was done as previously described (12). In brief, the techniques included: 1) bronchospirometry for the administration of different inspired mixtures to each lung, as well as the collection of expired gas from each lung separately; 2) cardiac catheterization with a triple lumen catheter to allow sampling and injection proximal and distal to the occlusive balloon; and 3) arterial cannulation.

The rate of blood flow through each lung was changed by inflating the balloon in one pulmonary artery. Blood flow was thus diminished to one lung and correspondingly increased in the opposite one.

The lung with the occluded pulmonary artery breathed 25 per cent $\mathrm{O}_{2}$, while the contralateral lung breathed 21 per cent $\mathrm{O}_{2}$. Following a 15 minute period of equilibration, each lung continued to breathe its own inspired mixture plus 0.1 per cent $\mathrm{CO}$ for an additional four minutes. Blood and gas samples for the calculation of $\mathrm{O}_{2}$ uptake, $\mathrm{CO}$ uptake, cardiac output and arterial blood $\mathrm{pCO}_{2}$ were collected during the last two minutes of the four minute period.

By this protocol, total blood flow may be calculated by dividing $\mathrm{O}_{2}$ uptake of both lungs by the corresponding arteriovenous difference for $\mathrm{O}_{2}$. The blood flow through the lung receiving 25 per cent $\mathrm{O}_{2}$ is calculated from its $\mathrm{O}_{2}$ uptake and the arteriovenous $\mathrm{O}_{2}$ difference across that lung, on the assumption that the pulmonary venous blood from that lung is $\mathbf{9 8}$ per cent saturated. The flow through the contralateral lung is measured as the difference between the total blood flow and the flow through the lung receiving the 25 per cent $\mathrm{O}_{2}$. For these measurements, it is assumed on the basis of previous studies in this laboratory that during occlusion of one pulmonary artery, there is no significant bronchial collateral circulation (13) to the compromised side.

For the calculation of the DLco for each lung separately, during both the control and test periods, separate estimates of pulmonary dead space were required: During the control period, dead space was calculated for each lung by the Bohr formula on the assumption that the arterial tension of carbon dioxide is equal to the alveolar tension of carbon dioxide. During the period of partial occlusion, the calculation was more indirect: a total dead space for both lungs was calculated by the Bohr relationship using the tidal volume, the fraction of $\mathrm{CO}_{2}$ in expired gas from both lungs and the arterial $\mathrm{pCO}_{2}$. The dead space of the lung through which flow was increased was similarly calculated from the arterial $\mathrm{pCO}_{2}$ and the expired fraction of $\mathrm{CO}_{2}$ from that lung. The dead space of the remaining lung was calculated as the difference between these two. Where occlusion of a pulmonary artery was complete, as in J. M., no estimate of physiologic dead space in that lung was possible; in this case, the control dead space was used in the calculations of DLco.

\section{CALCULATIONS}

In addition to the measurement of the diffusing capacity of the lung for carbon monoxide ( $\mathrm{DL}_{\mathrm{co}}$ ), the uptake of CO by the lung per minute $\left(\dot{\mathrm{V}}_{\mathrm{Co}}\right)$, and the ratio of the uptake of $\mathrm{CO}$ to the volume of $\mathrm{CO}$ inspired $\left(\mathrm{CO}_{F}\right)$ have been used as indices of the diffusing capacity.

The pulmonary diffusing capacity is calculated according to the following expression of Fick's law of diffusion :

$$
\mathrm{DL}_{\mathrm{CO}}=\frac{\dot{\mathrm{V}}_{\mathrm{CO}}}{\overline{\mathrm{P}}_{\mathrm{ACO}}-\overline{\mathrm{P}} \mathrm{cco}_{\mathrm{CO}}},
$$

where

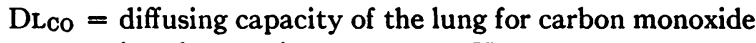
in $\mathrm{ml}$. per minute per $\mathrm{mm}$. $\mathrm{Hg}$,

$\dot{\mathrm{V}}_{\text {Co }}=$ uptake of carbon monoxide, ml. per minute,

$\overline{\mathrm{P}}_{\mathrm{ACO}}=$ mean alveolar carbon monoxide tension, $\mathrm{mm}$. $\mathrm{Hg}$ and

$\overline{\mathrm{P}} \mathrm{c}_{\mathrm{co}}=$ mean tension of carbon monoxide in pulmonary capillary blood, $\mathrm{mm}$. $\mathrm{Hg}$.

The uptake of $\mathrm{CO}$ is calculated from an analysis of inspired and expired fractions of $\mathrm{CO}$ using a nitrogen correction for metabolic gas exchange:

where

$$
\dot{\mathrm{V}}_{\mathrm{CO}}=\dot{\mathrm{V}}_{\mathrm{E}}\left(\frac{\mathrm{FE}_{\mathrm{N}_{2}}}{\mathrm{FI}_{\mathrm{N}_{2}}} \mathrm{~F}_{\mathrm{ICO}}-\mathrm{FE}_{\mathrm{CO}}\right) \text {, }
$$

$\dot{\mathrm{V}}_{\mathbf{E}}=$ total minute ventilation, L. per minute, STPD,

$\mathrm{FE}_{\mathrm{N}_{2}}=$ fraction of nitrogen in expired gas,

$\mathrm{FI}_{\mathrm{N}_{2}}=$ fraction of nitrogen in inspired gas,

Fico $=$ fraction of carbon monoxide in inspired gas and

$\mathrm{FE}_{\mathrm{CO}}=$ fraction of carbon monoxide in expired gas. 
The mean alveolar tension of $\mathrm{CO}$ is calculated from the Bohr dead space assuming that $\mathrm{VDCO}_{2}=\mathrm{VDCo}_{\mathrm{C}}$, so that:

$$
\overrightarrow{\mathrm{P}}_{\mathrm{ACO}}=\frac{\mathrm{V}_{\mathrm{T}}\left(\mathrm{PE}_{\mathrm{CO}}\right)-\mathrm{VDCO}_{2}\left(\mathrm{PICO}_{\mathrm{CO}}\right)}{\mathrm{V}_{\mathrm{T}}-\mathrm{VD}_{\mathrm{CO}_{2}}},
$$

where

$\mathrm{VDCO}_{2}=$ dead space for carbon dioxide based on arterial blood $\mathrm{pCO}_{2}$,

$V_{D_{C O}}=$ dead space for carbon monoxide and

$\mathrm{V}_{\mathrm{T}}=$ tidal volume, BTPS.

The fraction of $\mathrm{CO}$ taken up from inspired gas was calculated according to Filley, MacIntosh and Wright (6) as follows:

$\mathrm{CO}_{\mathrm{F}}=\frac{\dot{\mathrm{V}}_{\mathrm{CO}}}{\mathrm{V}_{\mathrm{E}}\left(\frac{\mathrm{FE}_{\mathrm{N}_{2}}}{\mathrm{FI}_{\mathrm{N}_{2}}} \mathrm{FI}_{\mathrm{ICO}}\right)}-\mathrm{V}_{\mathrm{D}}$ (instrument) (f) $+\left(F_{I_{C O}}-F_{A C O}\right)$,

where

$\mathrm{CO}_{\mathrm{F}}=$ ratio of the uptake of carbon monoxide to the volume of carbon monoxide inspired, per cent,

$F_{A C O}=$ fraction of carbon monoxide in alveolar gas and

$f=$ respiratory frequency, breaths per minute.

The arterial tension of $\mathrm{CO}$ was calculated from the Haldane relationship (8):

where

$$
\mathrm{Paco}=\frac{\mathrm{PaO}_{2} \cdot(\mathrm{COHb})}{210 \cdot\left(\mathrm{O}_{2} \mathrm{Hb}\right)},
$$

Paco = tension of carbon monoxide in arterial blood, $\mathrm{mm} . \mathrm{Hg}$,

$\mathrm{PaO}_{2}=$ tension of oxygen in arterial blood, $\mathrm{mm} . \mathrm{Hg}$,

$(\mathrm{COHb})=$ content of carboxyhemoglobin in arterial blood, volumes per cent,

$\left(\mathrm{O}_{2} \mathrm{Hb}\right)=$ content of oxyhemoglobin in arterial blood, volumes per cent and

$210=$ relative affinity constant for carbon monoxide and oxygen in blood.

RESULTS

\section{Rest and exercise}

The Dlco was measured at rest in 36 normal subjects. These individual measurements and the data from which they were derived appear in Tables $I$ and II. The average resting DLco for this entire group was $14.1 \mathrm{ml}$. per minute per $\mathrm{mm} . \mathrm{Hg}$.

The corresponding values for patients with rheumatic heart disease appear in Table IV. The average resting DLco for this group of subjects is $14.6 \mathrm{ml}$. per minute per $\mathrm{mm}$. $\mathrm{Hg}$, which is not significantly different $(p>0.05)$ from the normal subjects.

An analysis of the resting DLco according to sex, for both normal subjects and patients with rheumatic heart disease, is included in Table V. It may be seen that the mean resting value for the normal males (14.8) is higher than the mean resting value for normal females (11.5). This difference is only of suggestive statistical significance $(p<0.05)$.

It is of interest, that the mean DLco of the three male subjects in the rheumatic group is higher than the value in the normal subjects. However, the number of subjects is obviously too few for statistical comparison.

The diffusing capacity during exercise and the data from which they were derived are shown in Table II for normal subjects and in Table IV for subjects with rheumatic heart disease. It may be seen that each subject experienced an increase in diffusing capacity during exercise.

As is shown in Table $\mathrm{V}$, the mean Drco during exercise in normal subjects is slightly greater $(22.1 \mathrm{ml}$. per minute per $\mathrm{mm}$. $\mathrm{Hg}$ ) than the mean exercise Dico in subjects with rheumatic heart disease $(20 \mathrm{ml}$. per minute per $\mathrm{mm}$. $\mathrm{Hg})$. However, Table $\mathrm{V}$ also indicates that the normal subjects achieved a higher level of exercise (mean $\mathrm{O}_{2}$ uptake of $430 \mathrm{ml}$. per minute per $\mathrm{M} .^{2}$ ) than did subjects with rheumatic heart disease (mean $\mathrm{O}_{2}$ uptake of $320 \mathrm{ml}$. per minute per M. ${ }^{2}$ ). When this difference in level of exercise is taken into account by expressing the increase in DLco as per $100 \mathrm{ml}$. increase in oxygen uptake, both groups demonstrate an average increase in DLco of $1.9 \mathrm{ml}$. per minute per $\mathrm{mm}$. $\mathrm{Hg}$ per $100 \mathrm{ml}$. increase in $\mathrm{O}_{2}$ uptake.

In Figure 1, the DLco is related to minute ventilation and to pulmonary blood flow for both groups of subjects at rest and during exercise. It may be seen, in Figure 1A, that there is a good statistical correlation $(p<0.001)$ between DLco and the minute ventilation, at rest and during exercise; on the other hand, as seen in Figure 1B, the correlation between DLco and pulmonary blood flow is poorer $(p=0.01)$. Figure 1 emphasizes that during exercise, DLco increases in subjects with mitral stenosis in the face of abnormally low increments in pulmonary blood flow.

Figure 2 substitutes CO uptake for DLco and shows a similar type of relationship with minute ventilation and pulmonary blood flow. 
TABLE V

The diffusing capacity and fractional uptake of carbon monoxide at rest and during moderate exercise*

\begin{tabular}{|c|c|c|c|c|c|c|c|c|}
\hline \multicolumn{2}{|c|}{ Subjects } & \multirow[b]{2}{*}{ Age } & \multirow[b]{2}{*}{ State } & \multirow[b]{2}{*}{$\dot{\mathrm{V}}_{\mathrm{O} 2}$} & \multirow{2}{*}{\multicolumn{2}{|c|}{$\mathrm{DL}_{\mathbf{c o}}$}} & \multirow{2}{*}{\multicolumn{2}{|c|}{$\mathrm{CO}_{\mathrm{F}} \times 100$}} \\
\hline Sex & No. & & & & & & & \\
\hline & & yrs. & & $\operatorname{ml.} / \min . / M .^{2}$ & & ml. $/ \min . / m m . ~ H g$ & $\%$ & \\
\hline & & & & Normal subjects & & & & \\
\hline $\begin{array}{l}\text { Males } \\
\text { Females }\end{array}$ & $\begin{array}{r}28 \\
8\end{array}$ & $\begin{array}{l}(14-61) \\
(20-62)\end{array}$ & Rest & $\begin{array}{l}141(113-172) \\
143(126-175)\end{array}$ & $\begin{array}{l}14.8 \\
11.5\end{array}$ & $\begin{array}{l}(9.5-23.7) \pm 3.48 \\
(9.0-15.8) \pm 2.28\end{array}$ & $\begin{array}{l}47(36-60) \\
45(34-60)\end{array}$ & $\begin{array}{l} \pm 4.9 \\
\pm 8.2\end{array}$ \\
\hline $\begin{array}{l}\text { Males } \\
\text { Females }\end{array}$ & $\begin{array}{r}10 \\
5\end{array}$ & $\begin{array}{l}(14-44) \\
(20-44)\end{array}$ & Exercise & $\begin{array}{l}450(360-617) \\
391(296-531)\end{array}$ & $\begin{array}{l}23.3 \\
20.1\end{array}$ & $\begin{array}{l}(17.4-27.1) \pm 4.10 \\
(16.0-31.5) \pm 5.80\end{array}$ & $\begin{array}{ll}36 & (27-45) \\
34 & (28-41)\end{array}$ & $\begin{array}{l} \pm 4.8 \\
\pm 4.0\end{array}$ \\
\hline $\begin{array}{l}\text { Males } \\
\text { Females }\end{array}$ & $\begin{array}{r}3 \\
10\end{array}$ & $\begin{array}{l}(34-40) \\
(31-51)\end{array}$ & Rest & $\begin{array}{c}\text { Rheumatic heart di } \\
151(140-165) \\
139(112-176)\end{array}$ & $\begin{array}{l}\text { ase } \\
19.3 \\
13.2\end{array}$ & $\begin{array}{r}(14.0-27.1) \\
(9.1-22.5) \pm 5.6 \\
\end{array}$ & $\begin{array}{ll}54 & (50-59) \\
48 & (37-63)\end{array}$ & $\begin{array}{l} \pm 3.3 \\
\pm 7.4\end{array}$ \\
\hline $\begin{array}{l}\text { Males } \\
\text { Females }\end{array}$ & $\begin{array}{r}3 \\
10\end{array}$ & $\begin{array}{l}(34-40) \\
(31-57)\end{array}$ & Exercise & $\begin{array}{l}357(262-552) \\
305(193-420)\end{array}$ & $\begin{array}{l}27.9 \\
17.5\end{array}$ & $\begin{array}{l}(16.8-41.6) \pm 10.3 \\
(13.0-27.4) \pm 4.4\end{array}$ & $\begin{array}{l}40(35-45) \\
34(24-42)\end{array}$ & $\begin{array}{l} \pm 4.7 \\
\pm 6.5\end{array}$ \\
\hline
\end{tabular}

* Symbols as in Table I. Mean values are followed by range in parentheses; figures after range indicate standard deviation.

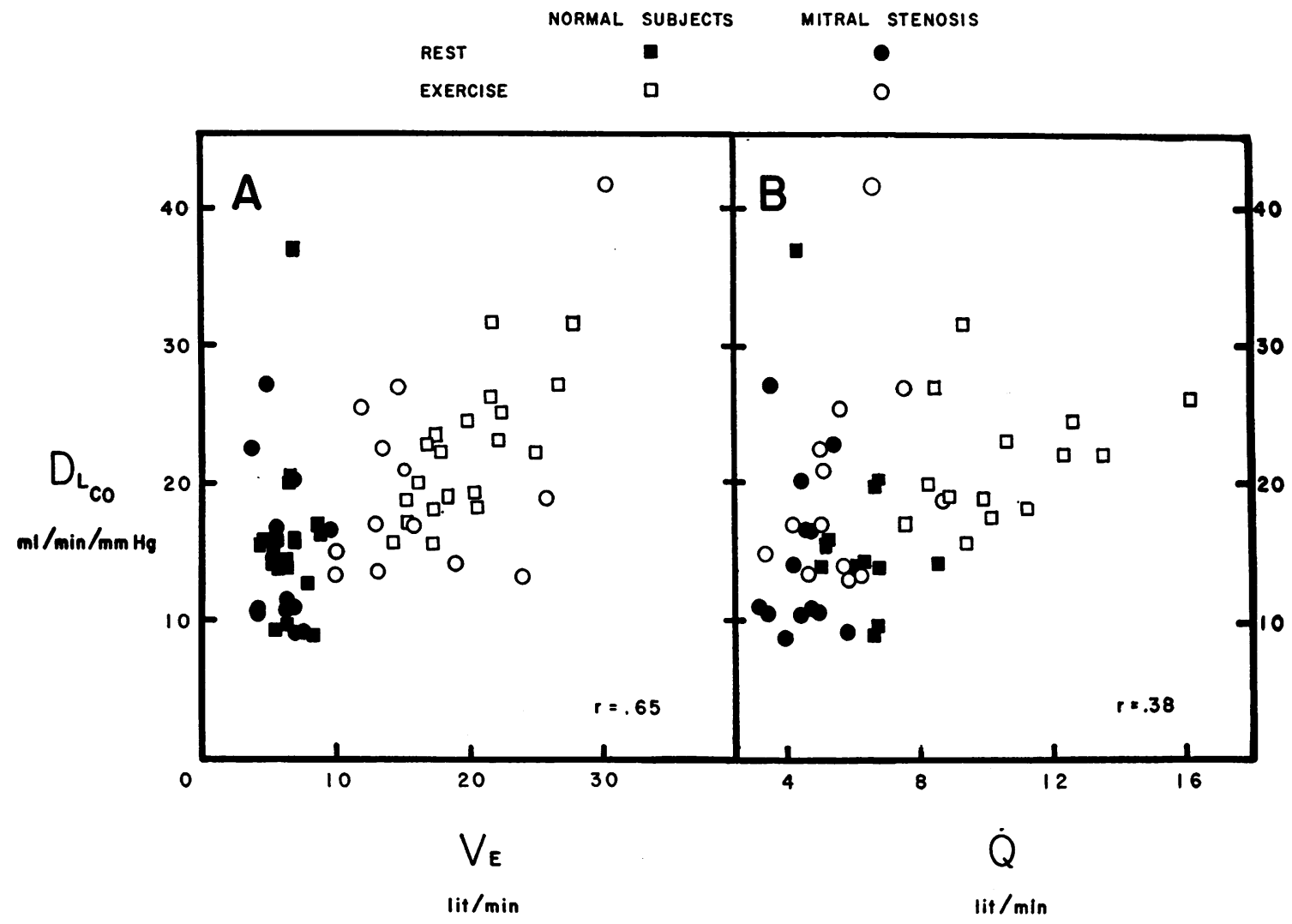

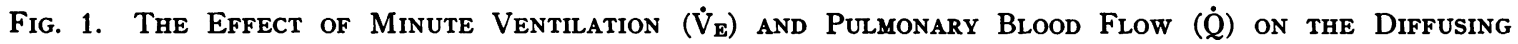
Capacity of the lung for Carbon Monoxide (Dlco) in Normal Subjects and in Patients with Mitral Stenosis, AT REST AND DURING EXercise

Although pulmonary blood flow increased only slightly during exercise in the patients with mitral stenosis, the DLco increased normally (Table V). 
Finally, as may be seen from Table V, the amount of $\mathrm{CO}$ removed from inspired air averaged 45 per cent in normal subjects at rest and decreased to 35 per cent during exercise. These mean values for patients with mitral stenosis are not significantly different $(p>0.05)$.

\section{Voluntary hyperpnea}

The data concerning minute ventilation, pulmonary blood flow and diffusing capacity during voluntary hyperpnea are listed in Tables II and IV. In all but three instances (M. M., L. S. and R. G.), the minute ventilation during voluntary hyperpnea was the same, or greater, than that during exercise. It may be seen that this deliberate augmentation of ventilation up to levels of $32 \mathrm{~L}$. per minute was associated with increases in cardiac output of only 20 per cent above the resting levels.

Figure 3 illustrates the relationship between DL $_{C O}$ and minute ventilation (Figure $3 \mathrm{~A}$ ) and
DLco and pulmonary blood flow (Figure 3B) in four normal subjects and one subject with mitral stenosis at rest, during exercise and during voluntary hyperpnea. It may be seen from Figure $3 \mathrm{~A}$ that as ventilation is increased, either by voluntary hyperpnea or exercise, the diffusing capacity also increases. However, as may be seen in Figure 3B, the increases in DL $\mathrm{L}_{\mathrm{Co}}$ during voluntary hyperpnea are independent of increases in pulmonary blood flow since: 1) In the rheumatic subject, the increases in DLco were unaccompanied by changes in blood flow either during voluntary hyperpnea or exercise, and 2) in the normal subjects, the largest increments in Dico occur during voluntary hyperpnea when blood flow was consistently less than during exercise.

In Figure 4A, minute ventilation is plotted against the uptake of carbon monoxide for the subjects of Figure 3. For the sake of reference, the line from Figure 1 relating these values

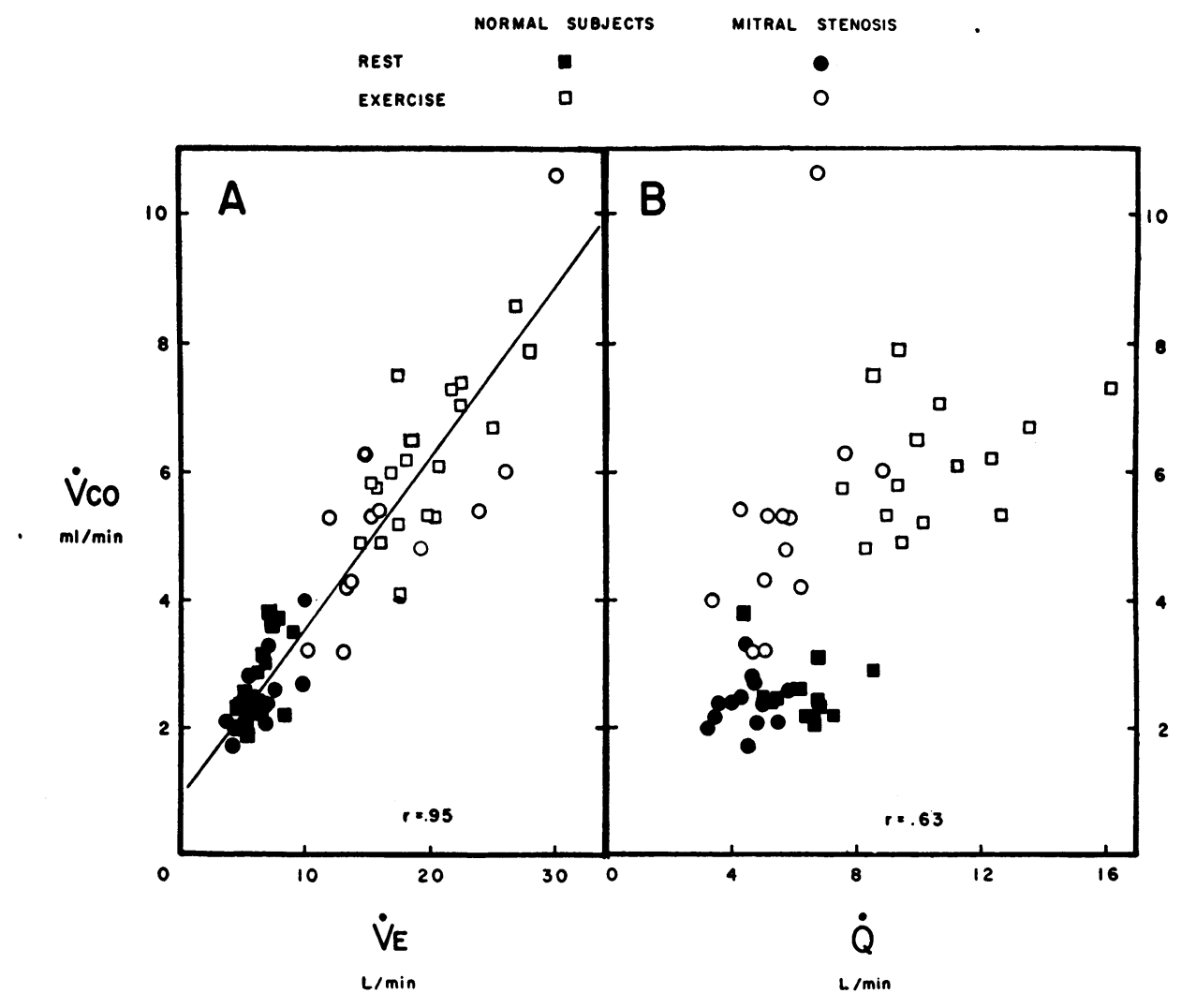

Fig. 2. The Effect of Minute Ventilation ( $\dot{V}_{E}$ ) and Pulmonary Blood Flow (Q) on the Uptake of Carbon Monoxide ( $\dot{V}_{\text {co }}$ ) in Normal Subjects and in Patients with Mitral Stenosis at Rest and Exercise 
during rest and exercise is also included. It may be seen that the relationship between the $\mathrm{CO}$ uptake and ventilation during voluntary hyperpnea is the same as that during exercise. As in the case of DLCo, Figure 4B illustrates that these increases in $\dot{\mathrm{V}}_{\text {Co }}$ during voluntary hyperpnea are also independent of changes in pulmonary blood flow.

The values for the fraction of $\mathrm{CO}$ removed from inspired air during voluntary hyperpnea are also included in Tables II and IV. It may be seen that the fraction of $\mathrm{CO}$ removed from inspired gas $\left(\mathrm{CO}_{\mathrm{F}}\right)$ is, in most instances, reciprocally related to the level of ventilation. Thus, when the level of ventilation during voluntary hyperpnea exceeded that during exercise, the $\mathrm{CO}_{F}$ was less than that during exercise. Conversely, when the level of ventilation during hyperpnea was less than that during exercise, the $\mathrm{CO}_{\mathrm{F}}$ was higher. However, in three subjects (J. J., E. M. and B. K.), even though minute ventilation during voluntary hyperpnea exceeded that during exercise, the $\mathrm{CO}_{\mathrm{F}}$ was higher.
In order to assess the effect of a change in ventilatory pattern on $\mathrm{DL}_{\mathrm{CO}}$, the respiratory frequency and tidal volume were varied in two subjects, C. C. and J. R., during two successive periods of voluntary hyperpnea. In both subjects, DLCo, $\dot{\mathrm{V}}_{\mathrm{CO}}$ and $\mathrm{CO}_{\mathrm{F}}$ were higher during breathing patterns of slow frequency and large tidal volume.

\section{Unilateral occlusion of one pulmonary artery}

In Table III are listed the data for the calculation of $D_{L_{C O}}, \dot{\mathrm{V}}_{\mathrm{CO}}$ and pulmonary blood flow (Q) for each lung separately. These data are also the basis for Figure 5 .

The values for oxygen uptake and pulmonary blood flow in Table III indicate that different degrees of occlusion of a pulmonary artery were accomplished in different subjects. Despite these changes in blood flow, minute ventilation in each lung remained relatively unaffected. As may be seen in Figure 5, the increases in blood flow had no appreciable affect on either $\mathrm{DL}_{\mathrm{Co}}$ or $\mathrm{V}_{\mathrm{CO}}$, even when blood flow increased by 230 per cent.

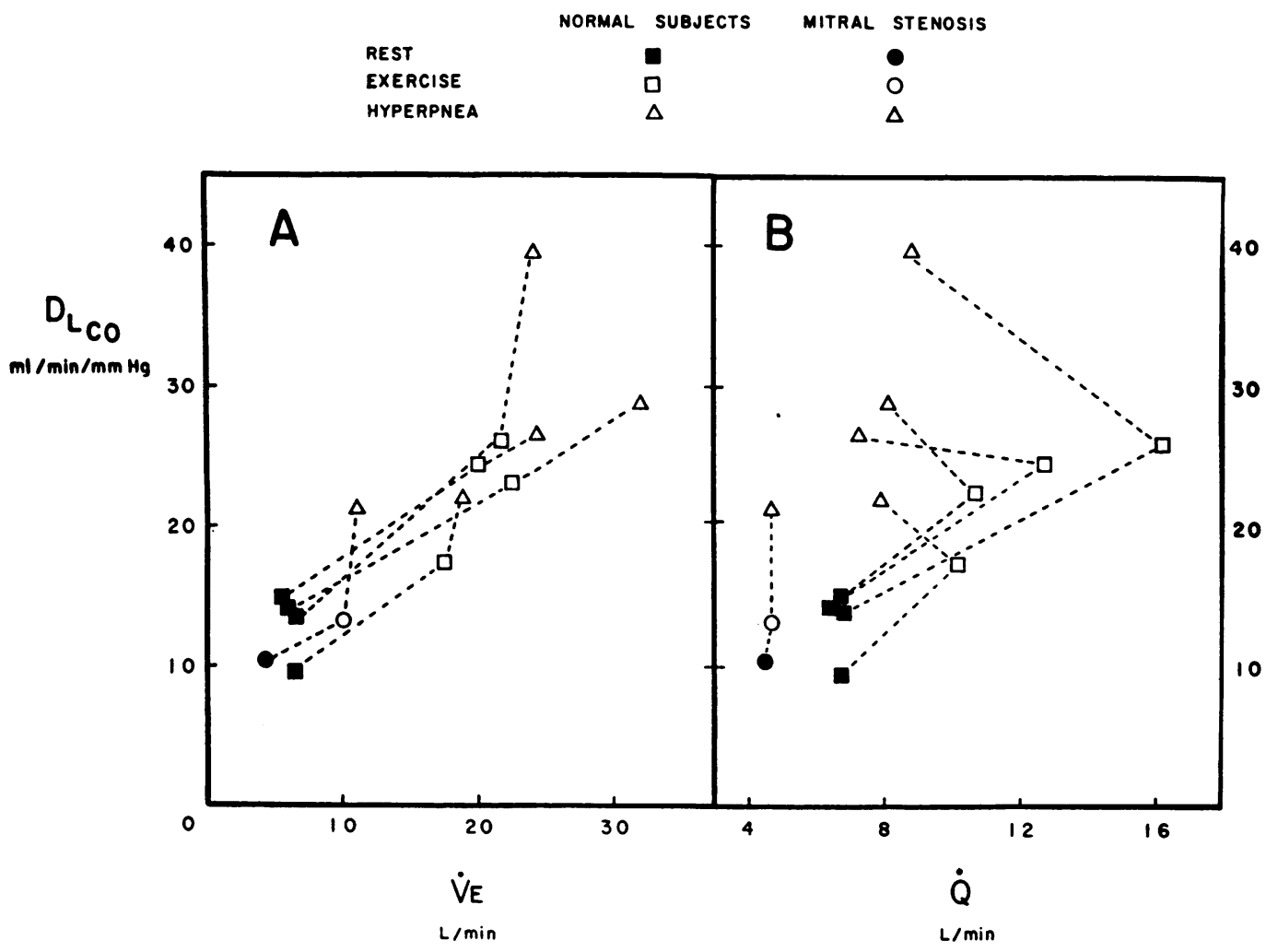

Fig. 3. The Effect of Minute Ventilation $\left(\dot{V}_{E}\right)$ and Pulmonary Blood Flow (Q) on the Diffusing Capacity of the lung for Carbon Monoxide (Dlco) During Rest, Exercise and Voluntary Hyperpane in Four Normal Subjects and One Patient with Mitral Stenosis 
Only when blood flow was severely curtailed, i.e., to less than 50 per cent of the control value, did a decrease in D $\iota_{C o}$ and $\dot{V}_{\text {Co }}$ become apparent.

Although the fraction of $\mathrm{CO}$ removed from inspired air tended to parallel the change in $\mathrm{DL}_{\mathrm{co}}$, individual results are difficult to assess because of unavoidable changes in ventilation between the control and the test periods.

\section{Relation between pulmonary artery pressure and $D_{L C O}$}

In the normal subjects, pulmonary artery pressures averaged $18 / 7 \mathrm{~mm} . \mathrm{Hg}$, with a mean of 12 at rest and increased to $25 / 11$, with a mean of 16 during exercise. In the patients with mitral stenosis (Table IV) pulmonary artery pressure was abnormally high at rest, averaging $46 / 21$ $\mathrm{mm} . \mathrm{Hg}$, with a mean of 31 ; during exercise, the average pulmonary artery pressure rose to $76 / 39$ $\mathrm{mm}$. $\mathrm{Hg}$, with a mean of 50 . Both groups of subjects failed to show any change in pulmonary artery pressure during voluntary hyperpnea.
No correlation was demonstrable between the level of pulmonary artery pressure and the DLCo in either group of subjects, either at rest or during exercise.

Effect of correction of tension of $\mathrm{CO}$ in arterial blood $\left(\mathrm{Pa}_{\mathrm{CO}}\right)$ on $\mathrm{DLCO}_{\mathrm{L} O}$

As expected, the tension of $\mathrm{CO}$ in arterial blood increased with the time of exposure to 0.1 per cent CO (14). The effect of this increase in $\mathrm{Paco}_{\mathrm{C}}$ on calculated $\mathrm{DL}_{\mathrm{CO}}$ is illustrated in Figure 6. It may be seen that when $\mathrm{Pa}_{\mathrm{Co}}$ is taken into account in the calculation of $D L_{c o}$, after six minutes of exposure at rest, the DL $\mathrm{L}_{\mathrm{Co}}$ increases by 5 to 10 per cent. The exercise $\mathrm{DL}_{\text {co }}$ after 12 minutes of exposure increased by 10 to 15 per cent, and after 18 minutes of exposure DLCo increased by 20 to 30 per cent.

\section{Sources of error in methods}

As may be seen from the equations above, and from the data in Tables I through V, the calcu-

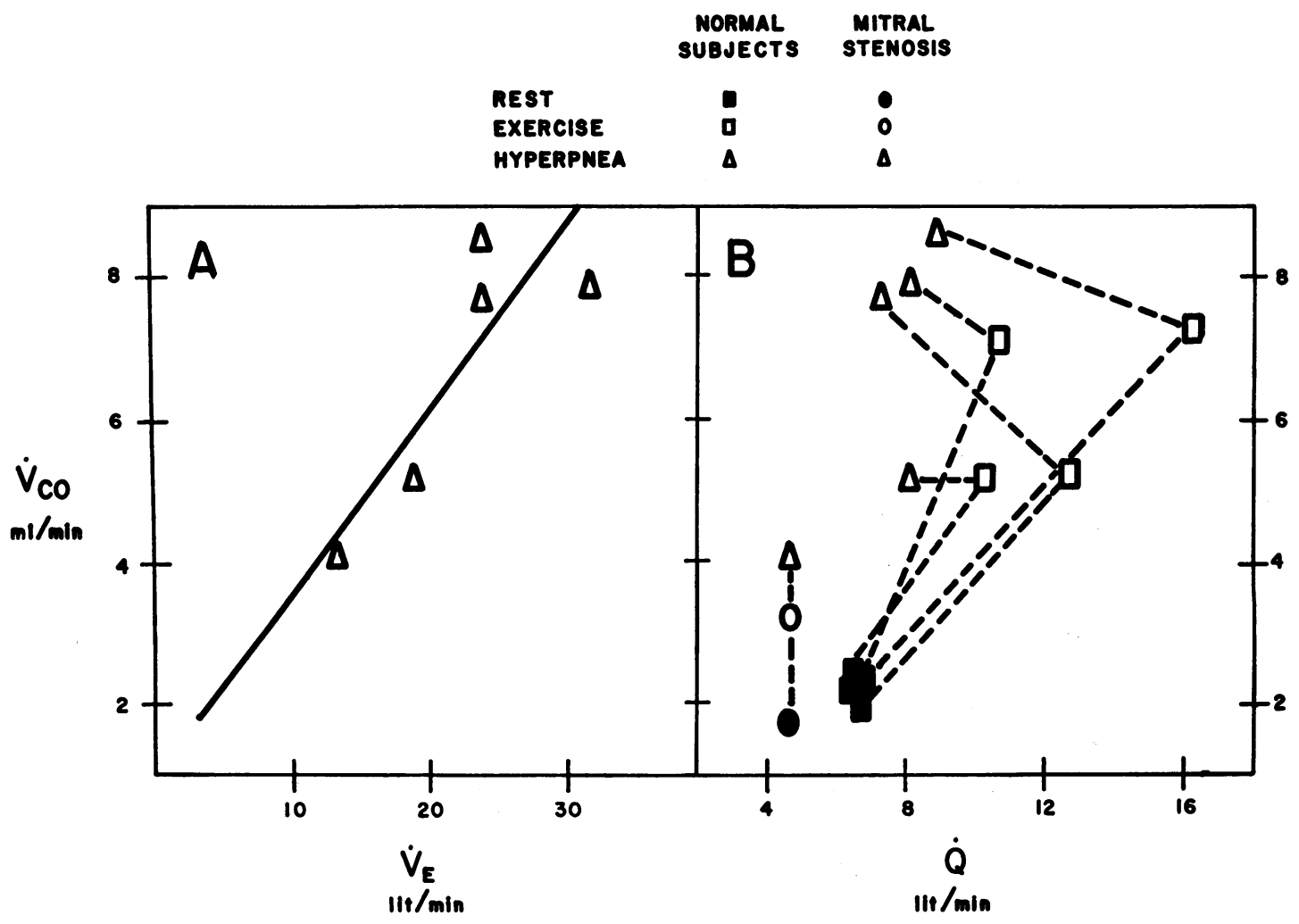

Fig. 4. The Effect of Minute Ventilation ( $\dot{V}_{\mathbb{E}}$ ) and Pulmonary Blood Flow (Q்) on the Uptake of Carbon Monoxide ( $\dot{V}_{\text {Co }}$ ) in the Subjects of Figure 3 During Rest, Exercise and Voluntary Hyperpnea The diagonal line in Figure 4A is derived from the data of Figure 1A by the method of least squares. 
lation of DLco by the steady state method affords ample opportunity for compounding errors. As indicated by Filley, MacIntosh and Wright (6), the major sources of error are 1 ) the measurement of arterial $\mathrm{pCO}_{2}$ by virtue of its effect on the calculation of the dead space and 2) the measurement of the expired fraction of carbon monoxide. By the nature of these errors, the estimation of $\mathrm{DL}_{\mathrm{Co}}$ by the steady state method is more accurate for high, rather than low, tidal volumes. Thus, at rest, where tidal volumes are small, the effect of the dead space volume on the calculation of $\mathrm{DL}_{\mathrm{CO}}$ is relatively large. An error of $2 \mathrm{~mm}$. in the measurement of arterial $\mathrm{pCO}_{2}$ may lead to an error of \pm 10 per cent in the DLCo by its effect on the dead space measurement. A concordant error in determination of expired $\mathrm{CO}$ of 2 per cent of full scale will increase the error in DLco to \pm 25 per cent.

When tidal volumes are large, as during exercise or during voluntary hyperpnea, the effect of changes in dead space volume on the calculation of alveolar pCO are less, so that errors from this source diminish. Also, at high tidal volumes, gross errors in $\mathrm{pCO}_{2}$ are readily apparent due to the unlikely dead space volumes which result. Assuming tidal volumes in the range of $2,000 \mathrm{ml}$., the combined effect of a $2 \mathrm{~mm}$. error in $\mathrm{PaCO}_{2}$ and a concordant 2 per cent error in expired $\mathrm{CO}$ lead to a 12 per cent error in DLco. Similarly, a change in $V_{D} / V_{T}$ ratio from 12 to 39 per cent during exercise or voluntary hyperpnea varies the DLco by approximately 9 per cent.

The use of the Fick principle for the measurement of pulmonary blood flow depends on the maintenance of steady state conditions. Although the performance of voluntary hyperpnea while breathing 3 or 5 per cent $\mathrm{CO}_{2}$ made the achievement of a steady state difficult, nonetheless, as seen in Tables II and IV, in all but four of the subjects (J. J., N. N., L.S. and I. R.) strict criteria for a steady state were fulfilled. In these four subjects, the respiratory quotient (R.Q.) was low. This low R.Q. presumably reflects a continuation of the unsteady state which obtains at the start of $\mathrm{CO}_{2}$ breathing when $\mathrm{CO}_{2}$ output is reduced because of storage of metabolic $\mathrm{CO}_{2}$ in body tissues (15). Under such circumstances, the $\mathrm{O}_{2}$ uptake by the lungs calculated from the fractions of $\mathrm{O}_{2}$ and $\mathrm{CO}_{2}$ in expired gas is artificially high. The high $\mathrm{O}_{2}$ uptake leads to an elevation of cardiac output calculated by the Fick principle. Such considerations suggest that in these subjects with a low R.Q. during voluntary hyperpnea, the actual increase in cardiac output was even less than indicated in Table V.

\section{DISCUSSION}

These different types of experiments are in accord in demonstrating a marked effect of minute ventilation on Dico. By way of contrast, they indicate that DLco is little affected by a change in pulmonary blood flow until flow is reduced well below 50 per cent of normal. They also offer some basis for speculation concerning the effect of the pulmonary blood volume on the pulmonary diffusing capacity.
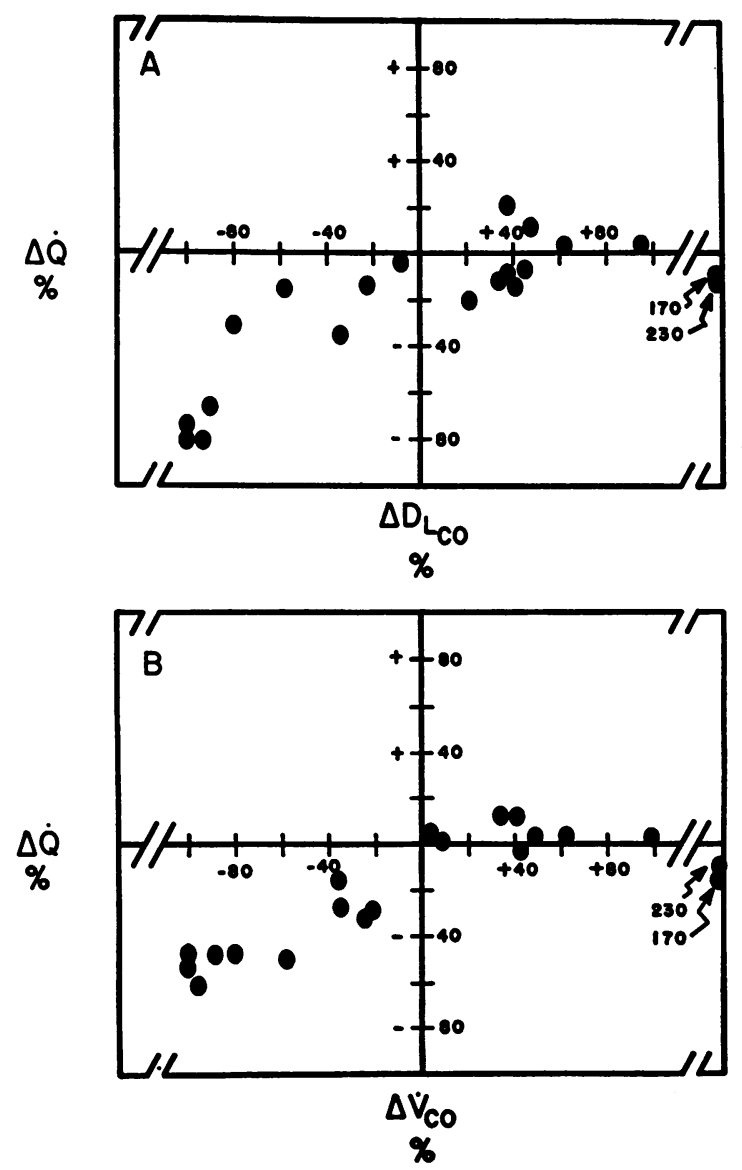

Fig. 5. The Effect of a Change in the Blood Flow Through Each Lung $(\% \Delta Q)$ on the Corresponding Diffusing Capacity for Carbon Monoxide ( $\% \Delta D_{\text {L }}$ co) (UPPER FIGURE) AND ON THE UPTAKE OF CO $\left(\% \Delta \dot{V}_{\mathrm{CO}}\right)$ (LOWER FIGURE) 


\section{Ventilation}

It is generally believed that during quiet breathing only a fraction of the alveolar surface is used for diffusion. During exercise, as minute ventilation increases, it is likely that the alveolarcapillary membrane is stretched and the area used for diffusion increases.

Previous indirect estimates of $\mathrm{DL}_{\mathrm{CO}}$, such as the fractional uptake of $\mathrm{CO}$ (16), as well as direct measurements by the single breath technique $(3,17)$, suggest that the volume of gas in the lung influences the area available for alveolarcapillary gas exchange. Some support for this point of view is brought forth in the present study, where an enlarged mean alveolar volume, presumably accomplished by slow deep breath- ing was associated with values of $\mathrm{DL}_{\mathrm{co}}$ greater than with usual breathing patterns.

It is pertinent to note that the relationship between the volume of alveolar gas and the DLCo may involve several less evident physiological adaptations: 1) a redistribution of blood within the lung so as to preserve $\mathrm{CO}$ gradients for diffusion, and 2) absolute increases in both blood flow $(18,19)$ and volume $(20)$ incident to respiratory maneuvers which involve deep or prolonged inspirations.

Although these hidden mechanisms cannot be assessed, it is nonetheless clear that methods for determining DL $_{\text {Co }}$ which involve increases in the mean alveolar gas volume such as the single breath technique of Forster, Fowler, Bates and

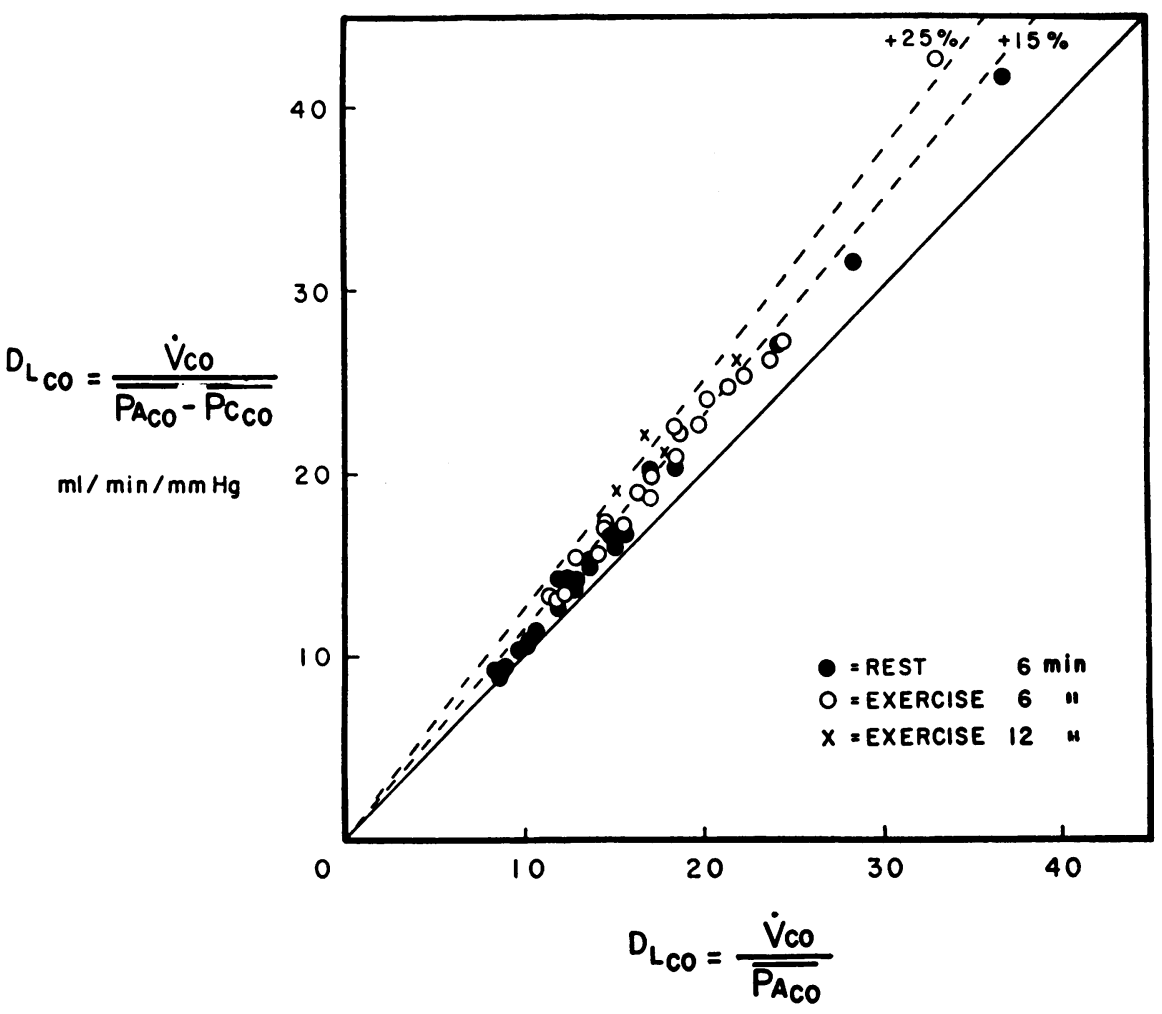

$\mathrm{ml} / \mathrm{min} / \mathrm{mm} \mathrm{Hg}$

Fig. 6. The Effect of an Estimated "Back Pressure" of Carbon Monoxide in Pulmonary Capillary Blood on the Calculated Value for Diffusing Capacity of THE LUNG

The values on the ordinate are calculated on the assumption that the mean tension of $\mathrm{CO}$ in arterial blood equals the mean tension of $\mathrm{CO}$ in the pulmonary capillary. The values for the abscissa are calculated on the assumption that the mean tension of $\mathrm{CO}$ in the pulmonary capillary is zero. 
Van Lingen (21) and the rebreathing technique of Kruhфffer (22) should yield larger values for DLCo at rest than do methods utilizing normal breathing patterns. These differences have been observed (23).

\section{Rate of pulmonary blood flow}

On the basis of calculations applied to data on $\mathrm{CO}$ uptake determined by Forbes, Sargent and Roughton (24), Hatch (25) concluded that at equilibrium the partition coefficient of $\mathrm{CO}$ between blood and air is of such high magnitude, that the rate of pulmonary blood flow should have a negligible effect on the transfer of gas from alveolar air to blood. These theoretical predictions of Hatch are supported by the results of the present study. A similar lack of relationship between uptake and blood flow would be expected for other gases whose partition coefficients are in the same order of magnitude (26). Consequently, these observations emphasize that as long as permeability of the pulmonary capillary membrane remains high, the factors limiting the uptake of such gases are the size of the diffusing surface and the volume of gas brought to it, rather than the rate of pulmonary blood flow.

With respect to the DLCo as a measure of the size of the capillary bed, it is of interest that a doubling of pulmonary blood flow did not appreciably alter $\mathrm{DL}_{\mathrm{CO}}$. Several possibilities may account for a lack of increase in capillary area: 1) that the capillaries were already distended by the supine position to a point where an increase in blood flow could be accommodated with no further increase in luminal size; 2) that the increased pulmonary blood flow was accommodated by opening of new capillaries which are in contact with poorly ventilated alveoli; or 3) that the change in DLCo was too small to be detected by these methods. The data do not allow distinction among these possibilities.

It is easier to rationalize a reduction in $\dot{V}_{\mathrm{CO}}$ and $\mathrm{DL}_{\mathrm{CO}}$ when blood flow is severely curtailed to the point of decreasing perfusion pressures and capillary blood volume. This situation exists distal to an occlusive balloon in a pulmonary artery (27) and such reduction in $\dot{\mathrm{V}}_{\mathrm{CO}}$ and D $\mathrm{L}_{\mathrm{CO}}$ have been observed. The possibility arises that stagnation of pulmonary blood distal to the bal- loon may contribute to the reduction in $\dot{\mathrm{V}}_{\mathrm{Co}}$ and Dico. That stagnation is of little significance in this regard is suggested by: 1) the reduction in DLCo during partial occlusion of a pulmonary artery when flow continues at a considerable, though reduced rate and 2) the insufficient saturation of pulmonary capillary blood with $\mathrm{CO}$ during brief complete occlusion of a pulmonary artery. Thus, it can be shown that in a lung with an assumed capillary blood volume of 30 $\mathrm{ml}$. and a measured $\mathrm{CO}$ uptake of $0.4 \mathrm{ml}$. per minute, the critical saturation of approximately 30 per cent would not be reached during the four minutes of $\mathrm{CO}$ breathing.

\section{Relationship between $D L_{C o}$ and pulmonary artery pressure}

Pulmonary hypertension from mitral stenosis is associated with an elevation of pressure in the pulmonary capillaries (28). As a consequence, the capillaries may be distended and the area available for diffusion increased. It was observed in this study, that subjects with mitral stenosis had a normal diffusing capacity for CO. This normal value may therefore represent a balance between anatomic alteration of the smaller pulmonary vessels and an increase in the pulmonary capillary blood volume.

In contrast to the pulmonary capillary hypertension of mitral stenosis, the experiments involving unilateral occlusion of a pulmonary artery resulted in a lowering of pulmonary vascular pressure and possibly capillary blood volume distal to the occluding balloon. In these experiments, as would be anticipated, the DLCo of the affected lung was decreased.

\section{Pulmonary blood volume}

In the absence of any direct measurement of pulmonary capillary blood volume, changes in this variable can only be inferred. There is indirect evidence (29) that the central blood volume increases in the supine position; the pulmonary capillaries may well share in this increase (30). Such a mechanism was invoked by Bates and Pearce (31) to explain the higher resting diffusing capacity in the supine position for both single breath and steady state methods. The supine position has also been shown to effect a more uniform distribution of blood and inspired gas 
in the lungs, particularly with regard to the upper lobes (32).

These considerations suggest that the increase in DLco during voluntary hyperpnea when blood flow remains virtually unchanged may reflect, in part, an increase in alveolar capillary blood volume. They also indicate that even though pulmonary blood flow has little effect on DLco, the effect of the volume and distribution of blood in the lung may be appreciable.

\section{The increase in $D L_{C o}$ during exercise}

Even though an attempt has been made in this study to isolate some of the individual factors which determine the diffusing capacity of the lung, it is apparent that under most physiological circumstances their interplay is so complicated as to make this type of distinction extremely difficult. This is particularly true of studies done during exercise where ventilation, pulmonary blood flow and possibly pulmonary blood volume all are increased. However, the data from this study do indicate that the increase in diffusing capacity for carbon monoxide, observed during mild to moderate exercise, is related to the increase in ventilation rather than to the increase in pulmonary blood flow. This conclusion is supported by the recent observations of others (33).

\section{SUMMARY AND CONCLUSIONS}

1. The effect of minute ventilation and pulmonary blood flow on the diffusing capacity of the lung for carbon monoxide was investigated at rest and during exercise by steady state methods.

2. For this purpose, normal subjects were contrasted with patients in whom pulmonary blood flow had been restricted by mitral stenosis.

3. In order to vary ventilation and blood flow independently, special methods, such as voluntary hyperpnea and unilateral occlusion of a pulmonary artery, were also employed.

4. The results indicate that diffusing capacity for carbon monoxide is little affected by changes in pulmonary blood flow until flow is markedly reduced. By way of contrast, increases in ventilation are associated with increases in diffusing capacity, and seem to account for the rise in diffusing capacity observed during moderate exercise.

\section{ACKNOWLEDGMENT}

We are indebted to the following members of the Cardiorespiratory Laboratory for their help in the performance of these studies: Drs. E. H. Bergofsky, R. W. Briehl, R. M. Goldring, A. G. Jameson and G. A. Laurenzi. We are also grateful to Dr. D. W. Richards for encouragement and advice.

\section{REFERENCES}

1. Krogh, M. The diffusion of gases through the lungs of man. J. Physiol. 1915, 49, 271.

2. Ogilvie, C. M., Forster, R. E., Blakemore, W. S., and Morton, J. W. A standardized breath holding technique for the clinical measurement of the diffusing capacity of the lung for carbon monoxide. J. clin. Invest. 1957, 36, 1.

3. Shephard, R. J. Breath-holding measurement of carbon monoxide diffusing capacity; comparison of a field test with steady-state and other methods of measurement. J. Physiol. 1958, 141, 408.

4. Roughton, F. J. W., and Forster, R. E. Relative importance of diffusion and chemical reaction rates in determining rate of exchange of gases in the human lung, with special reference to true diffusing capacity of pulmonary membrane and volume of blood in the lung capillaries. J. appl. Physiol. 1957, 11, 290.

5. Gibson, Q. H., Kreuzer, F., Meda, E., and Roughton, F. J. W. The kinetics of human haemoglobin in solution and in the red cell at $37^{\circ} \mathrm{C}$. J. Physiol. $1955,129,65$.

6. Filley, G. F., MacIntosh, D. J., and Wright, G. W. Carbon monoxide uptake and pulmonary diffusing capacity in normal subjects at rest and during exercise. J. clin. Invest. 1954, 33, 530.

7. Allen, T. H., and Root, W. S. An improved palladium chloride method for the determination of carbon monoxide in blood. J. biol. Chem. 1955, 216, 319.

8. Douglas, C. G., Haldane, J. S., and Haldane, J. B. S. The laws of combination of haemoglobin with carbon monoxide and oxygen. J. Physiol. 1912, 44, 275.

9. Van Slyke, D. D., and Sendroy, J., Jr. Studies of gas and electrolyte equilibria in blood. XV. Line charts for graphic calculations by the HendersonHasselbalch equation, and for calculating plasma carbon dioxide content from whole blood content. J. biol. Chem. 1928, 79, 781.

10. Van Slyke, D. D., and Neill, J. M. The determination of gases in blood and other solutions by vacuum extraction and manometric measurement. I. J. biol. Chem. 1924, 61, 523.

11. Scholander, P. F. Analyzer for accurate estimation of respiratory gases in one-half cubic centimeter samples. J. biol. Chem. 1947, 167, 235.

12. Fishman, A. P., Himmelstein, A., Fritts, H. W., Jr., and Cournand, A. Blood flow through each lung in man during unilateral hypoxia. J. clin. Invest. $1955,34,637$. 
13. Fishman, A. P., Turino, G. M., Brandfonbrener, M., and Himmelstein, A. The "effective" pulmonary collateral blood flow in man. J. clin. Invest. 1958, 37, 1071.

14. Linderholm, H. On the significance of $\mathrm{CO}$ tension in pulmonary capillary blood for determination of pulmonary diffusing capacity with the steady state $\mathrm{CO}$ method. Acta med. scand. 1957, 156, 413.

15. Rahn, H., and Fenn, W. O. A graphical analysis of the respiratory gas exchange. Amer. Physiol. Soc. Washington, D. C., 1955.

16. Bates, D. V. The uptake of carbon monoxide in health and in emphysema. Clin. Sci. 1952, 11, 21.

17. Marks, A., Cugell, D. W., Cadigan, J. B., and Gaensler, E. A. Clinical determination of the diffusion capacity of the lungs. Amer. J. Med. 1957, 22, 51.

18. Baxter, I. G., and Pearce, J. W. Simultaneous measurement of pulmonary arterial flow and pressure using condenser manometers. J. Physiol. 1951, 115,410 .

19. Dubois, A. B., and Marshall, R. Measurements of pulmonary capillary blood flow and gas exchange throughout the respiratory cycle in man. J. clin. Invest. 1957, 36, 1566.

20. Fowler, R. C., Guillet, M., and Rahn, H. Lung volume changes with positive and negative pulmonary pressures in Studies in Respiratory Physiology, W. O. Fenn, A. B. Otis, and H. Rahn, Eds. Air Force Tech. Report \# 6528, Aug. 1951.

21. Forster, R. E., Fowler, W. S., Bates, D. V., and Van Lingen, B. The absorption of carbon monoxide by the lungs during breathholding. $\mathrm{J}$. clin. Invest. 1954, 33, 1135.

22. Kruhфffer, P. Studies on lung diffusion coefficient for $\mathrm{CO}$ in normal human subjects by means of $\mathrm{C}^{14} \mathrm{O}$. Acta physiol. scand. 1954, 32, 106.

23. Forster, R. E. Exchange of gases between alveolar air and pulmonary capillary blood: Pulmonary diffusing capacity. Physiol. Rev. 1957, 37, 391.

24. Forbes, W. H., Sargent, F., and Roughton, F. J. W. The rate of carbon monoxide uptake by normal men. Amer. J. Physiol. 1945, 143, 594.

25. Hatch, T. F. Carbon monoxide uptake in relation to pulmonary performance. A. M. A. Arch. industr. Hyg. 1952, 6, 1.

26. Kety, S. S. Theory and application of exchange of inert gas at lungs and tissues. Pharmacol. Rev. 1951, 3, 1 .

27. Brandfonbrener, M., Turino, G. M., Himmelstein, A., and Fishman, A. P. Effects of occlusion of one pulmonary artery on pulmonary circulation in man. Fed. Proc. 1958, 17, 19.

28. Eliasch, $H$. The pulmonary circulation at rest and on effort in mitral stenosis. Scand. J. clin. Lab. Invest. 1952, 4, suppl. 4.

29. Lagerlöf, H., Eliasch, H., Werkö, L., and Berglund, E. Orthostatic changes of the pulmonary and peripheral circulation in man. Scand. J. clin. Lab. Invest. $1951,3,85$.

30. Hamilton, W. F., and Morgan, A. B. Mechanism of the postural reduction in vital capacity in relation to orthopnea and storage of blood in the lungs. Amer. J. Physiol. 1932, 99, 526.

31. Bates, D. V., and Pearce, J. F. The pulmonary diffusing capacity; a comparison of methods of measurement and a study of the effect of body position. J. Physiol. 1956, 132, 232.

32. Martin, C. J., Cline, F., Jr., and Marshall, H. Lobar alveolar gas concentrations : Effect of body position. J. clin. Invest. 1953, 32, 617.

33. Ross, J. C., Frayser, R., and Hickam, J. B. A study of the means by which exercise increases the pulmonary diffusing capacity for carbon monoxide (abstract). J. clin. Invest. 1958, 37, 926. 